\title{
Biofilm Formation Controlled by Quartz Crystal Nanobalance
}

\author{
J. Telegdi ${ }^{1}$, A. Shaban ${ }^{1}$, J. Beczner ${ }^{2}$, Zs. Keresztes ${ }^{1}$ and E. Kálmán ${ }^{1}$ \\ ${ }^{1}$ Central Research Institute for Chemistry, Hungarian Academy of Sciences, \\ Pf. 17, HU-1525 Budapest, Hungary \\ ${ }^{2}$ Central Food Research Institute, Pf. 393, HU-1536 Budapest, Hungary
}

Keywords: Quartz Crystal Microbalance, Microbiologically Influenced Corrosion, Aerobe and Anaerobe Bacteria, Desulfovibrio Desulfuricans, Cooling Water, Biocide

\begin{abstract}
Chemicals of systematically changed structure were synthesized in order to reduce the activity of aerobic and/or anaerobic bacteria, to inhibit the exopolymer, mainly exopolysaccharide secretion and the metal corrosion, at the same time. The efficiency was parallel monitored by different techniques as microbiological and gravimetric methods. As traditional measuring techniques can only characterize a relatively thick biofilm a new application of quartz crystal nanobalance became an extremely sensitive device to monitor the biofilm formation in the early period and the influence of different biocides on the film formation. Environmentally acceptable chemicals of two different efficiencies i.e. molecules with combined, anticorrosion and biofilm-formation-inhibiting activity were found.
\end{abstract}

\section{Introduction}

Corrosion associated with microorganisms was mentioned about 80 years ago [1], yet the efficient study of microbiologically influenced corrosion [MIC] is a relatively new field that needs specialists from multidisciplinary fields.

The MIC is a complex process that involves aerobic, facultative aerobic and anaerobic bacteria of different physiological behavior and nutrition requirements. The most dangerous ones are the desulfovibrios.

Cooling towers provide optimum conditions for microbial growth.

The role of microbes in the corrosion process is mainly due to their metabolisms associated with microbial growth and reproduction. In general, planktonic bacteria populations are smaller then sessile ones [2]. Fouling and corrosion are frequently mediated by microorganisms attached to the metal surface and/or embedded in gelatinous matrix termed biofilm. As the local attack of the microbes attached to the metal surface causes the most severe problem, it is important to control the adhesion in the early period. The bacteria attached irreversibly within a few hours produce exopolymers, mainly exopolysaccharides [EPS] that are the main component of a biofilm. This process is due to biologically mediated adhesion mainly by polyanionic molecules. Biofilms substantially change the local chemistry and, thereby, enhance corrosion processes [3].

Protection of materials against microbial corrosion include coatings, controlled dosage of appropriate chemicals termed biocides and change in environmental conditions unfavorable to microbial growth.

The most commonly used biocides that control the growth of microbes in cooling water systems could be classified as oxidizing/non-oxidizing chemicals or membrane active/electrophylically 
active biocides. Methods for evaluation of MIC can be microbiological/chemical and/or physical tests, that can enumerate the sessile and the planktonic bacteria or give on-line or off-line information on the kinetics. The microbial biofilm is a complex, heterogeneous microbial ecosystem that is difficult to study by conventional microbiological techniques.

The main objective of our research was to elaborate a new, reproducible technique for monitoring biofilm formation and EPS secretion induced by aerobic/anaerobic bacteria and for evaluation of efficiency of different biocides that inhibit the deposit formation. The quartz crystal nanobalance [QCNB] can be used in monitoring different processes like adsorption/desorption, metal/alloy plating, surface oxidation, etching, heterogeneous polymerization, coadsorption and competitive adsorption etc. as an extremely sensitive device $[4,5,6]$. The biofilm can deposit onto one side of the quartz crystal oscillator of which resonance frequency sensitively depends on the vibrating mass. As the change in mass in our case was supposed to be the consequence of the biofilm formation, in in situ experiment was this process followed. The analog resolution of our nanobalance is $0.1 \mathrm{~Hz}$ which corresponds approximately to $0.1 \mathrm{ng}$ of the mass change. The exceptional linearity of mass measurements extends up to $100 \mu \mathrm{g}$. The effect of the temperature can be neglected at room temperature.

The research was also focused on chemicals with combined, anticorrosion and biocidal activity in order to diminish the environmental pollution and to get deeper insight into the mechanisms of the EPS excretion.

\section{Materials and Methods}

The influence of hydroxymethylated series of chemicals with systematically changed structure (in the concentration range of $100-1000 \mathrm{ppm}$ ) on growth and multiplication of microbes and on different metals was monitored by different techniques like gravimetric and microbiological methods in order to get quantitative or semi-quantitative information on the MIC and on the efficiency of chemicals synthesized in our laboratory. ELCHEMA EQCN-700 quartz crystal nanobalance (resolution: frequency difference $0.1 \mathrm{~Hz}$, mass change $0.1 \mathrm{ng}$, operating parameters: reference crystal frequency $10.000 \mathrm{MHz}$, power supply $220 \mathrm{~V} / 50 \mathrm{~Hz}$, measurement range: frequency difference 0 to $5,000,000 \mathrm{~Hz}$, mass change -100.0 to $+100.0 \mathrm{ng}$ ) monitored the exopolymer secretion and the efficiency of the biocides on the biofilm formation.

Microbes used in the experiments were Desulfovibrio desulfuricans [ATCC 7757] and the mixed culture of industrial cooling water.

\section{Results and Discussion}

\section{Antimicrobial activity of chemicals}

The influence of chemicals that controlled the sessile and planktonic anaerobic and/or aerobic cultures is summarized in Table 1 . All of these biocides inhibited the Desulfovibrio desulfuricans effectively, and only with a few exceptions they gave good results in mixed culture of cooling water. The difference in the cell counts got with the same chemicals for sessile and planktonic population indicates the importance of the molecular character. The long-term biocidal efficiencies summarized in Table 2 show that after two weeks the majority of the chemicals under investigation still controlled effectively the multiplication of bacteria under both anaerobic and aerobic conditions. 
Table 1. Effect of biocides on Desulfovibrio desulfuricans and on microbes in cooling water

\begin{tabular}{|c|c|c|c|c|c|c|}
\hline $\begin{array}{l}\text { biocid } \\
\text { R-NH- }\end{array}$ & ppm & Cells & & 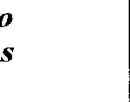 & & \\
\hline & & & 2 days & 7 days & 2 days & 7 days \\
\hline control & & sessile & $7.3 \times 10^{4}$ & & $3.4 \times 10^{6}$ & $2.4 \times 10^{3}$ \\
\hline & & planktonic & $3.4 \times 10^{7}$ & & $5.3 \times 10^{3}$ & $2.4 \times 10^{3}$ \\
\hline $\mathbf{H}$ & 500 & sessile & $>2.8 \times 10^{7}$ & $<10$ & $1.9 \times 10$ & $<10$ \\
\hline & & planktonic & $<10$ & $<10$ & $<10$ & $<10$ \\
\hline & 1000 & sessile & $2.7 \times 10$ & $<10$ & $<10$ & $<10$ \\
\hline & & planktonic & $<10$ & $<10$ & $<10$ & $<10$ \\
\hline $\mathrm{C} 6 \mathrm{H5}$ & 1000 & sessile & $<10$ & $<10$ & $5.1 \times 10$ & $<10$ \\
\hline & & planktonic & $<10$ & $<10$ & $2.2 \times 10$ & $<10$ \\
\hline $\mathrm{C}_{6} \mathrm{H}_{5}-\mathrm{CH}_{2}$ & 500 & sessile & $<10$ & $1.1 \times 10^{2}$ & $<10$ & $1.7 \times 10$ \\
\hline & & planktonic & $<10$ & $1.8 \times 10$ & $<10$ & $4.4 \times 10$ \\
\hline HOC6H4 & 500 & sessile & $<10$ & - & $<10$ & - \\
\hline & & planktonic & $<10$ & - & $<10$ & - \\
\hline $\begin{array}{l}\mathrm{HOOC}- \\
\left(\mathrm{CH}_{2}\right)_{2}\end{array}$ & 500 & sessile & $1.4 \times 10$ & $2.2 \times 10^{2}$ & $1.7 \times 10$ & $8.7 \times 10$ \\
\hline & & planktonic & $<10$ & $1.5 \times 10$ & $<10$ & $2.3 \times 10^{3}$ \\
\hline $\mathrm{C}_{8} \mathrm{H}_{6} \mathrm{~N}-\mathrm{CH}_{2}$ & 500 & sessile & $3.3 \times 10$ & $5.6 \times 10^{2}$ & $1.9 \times 10$ & $4.3 \times 10^{3}$ \\
\hline & & planktonic & $<10$ & $2.7 \times 10^{2}$ & $<10$ & $1.7 \times 10^{5}$ \\
\hline
\end{tabular}

Table 2 Results of the two-week experiments

(biocide concentration:500ppm; planktonic cell count)

\begin{tabular}{|c|c|c|}
\hline $\begin{array}{c}\text { biocide: } \mathbf{R}-\mathrm{NH}-\mathrm{Q} \\
\mathbf{Q}\end{array}$ & Desulfovibrio desulfuricans & mixed culture in cooling water \\
\hline control & $4.3 \times 10^{4}$ & $4.3 \times 10^{5}$ \\
\hline $\mathrm{C}_{6} \mathrm{H}_{5}-\mathrm{CH}_{2}$ & $2.4 \times 10^{2}$ & $9.3 \times 10^{5}$ \\
\hline$\left(\mathrm{CH}_{3}\right)_{2} \mathrm{CH}-\mathrm{CH}_{2}$ & $2.2 \times 10^{2}$ & $4.1 \times 10^{4}$ \\
\hline $\mathrm{HOOC}-\left(\mathrm{CH}_{2}\right)_{2}$ & $3.1 \times 10^{2}$ & $5.0 \times 10^{4}$ \\
\hline $\mathrm{C}_{8} \mathrm{H}_{6} \mathrm{~N}-\mathrm{CH}_{2}$ & $2.8 \times 10^{2}$ & $9.3 \times 10^{5}$ \\
\hline
\end{tabular}


Anticorrosion activity of chemicals

As our primary aim was to develop chemicals with combined, biocidal and anticorrosive activity, in corrosion tests the efficacy was also monitored. Results in Table 3 show that one of the most effective biocides accelerated the corrosion of mild steel, but the others resulted in good or acceptable corrosion inhibiting properties.

Table 3 In sterile and non-sterile cooling water corrosion inhibiting efficiency of chemicals and their biocidal efficacy

\begin{tabular}{|c|c|c|c|c|}
\hline \multirow{2}{*}{$\begin{array}{c}\text { chemicals } \\
\text { R-NH-Q } \\
\mathbf{Q} \\
\end{array}$} & \multicolumn{2}{|c|}{$\begin{array}{c}\text { corrosion inhibiting efficiency } \\
{[\%]}\end{array}$} & \multicolumn{2}{|c|}{ efficiency against } \\
\hline & cooling water & $\begin{array}{c}\text { sterile cooling } \\
\text { water }\end{array}$ & $\begin{array}{l}\text { Desulfovibrio } \\
\text { desulfuricals }\end{array}$ & $\begin{array}{c}\text { mixed culture of } \\
\text { cooling water }\end{array}$ \\
\hline $\mathbf{H}$ & -13.2 & 2.2 & good & very good \\
\hline $\mathrm{C}_{6} \mathrm{H}_{5}$ & 10.4 & 34.6 & very good & very good \\
\hline $\mathrm{C}_{6} \mathrm{H}_{5}-\mathrm{CH}_{2}$ & 85.4 & 74.9 & very good & good \\
\hline $\mathrm{HO}-\mathrm{C}_{6} \mathrm{H}_{4}$ & 34.2 & 43.3 & very good & very good \\
\hline
\end{tabular}

Results of the quartz crystal nanobalance measurements

As traditional measuring techniques can only characterize a biofilm when it is already thick, first time was the quartz crystal nanobalance used as an extremely sensitive device for monitoring the biofilm formation and the inhibiting effect of those chemicals that already showed biocidal efficiency on planktonic/sessile, aerobic/anaerobic population in microbiological experiments.

Results got by the nanobalance summarized in Table 4 show that this is an effective testing method for monitoring the biofilm formation and inhibition. Not only the EPS excretion but also its inhibition is a heterogeneous process The structure of the chemicals influences negatively the biocidal efficiency only in those cases if they contain (negatively or positively) charged atoms or groups. This could be due to the hydrophobic character of the bacterial membrane and to the polyanionic character of the EPS.

The cell count of the sessile population and the weight of the biofilm measured by QCNB in the presence of different chemicals enlighten that without hydrophobic side chain not the microbial adhesion but the EPS secretion is inhibited. The presence of a charged group in the biocide enhances the EPS excretion but decreases the rate of the adhesion.

All these results will help us in the future to plan new, multifunctional, more effective chemicals with corrosion inhibiting and biocidal activity. 
Table 4 Efficiency of biocides on biofilm formation measured by quartz crystal nanobalance at room temperature, in cooling water and with Desulfovibrio desulfuricans

\begin{tabular}{|c|c|c|c|c|}
\hline R-NH-Q & $\begin{array}{l}\Delta \mathrm{m} \text { (1.day) } \\
{[\mathrm{ng} / 6000 \mathrm{~s}]}\end{array}$ & $\begin{array}{c}\eta \\
{[\%]}\end{array}$ & $\begin{array}{l}\Delta m(5 . d a y) \\
{[n g / 6000 \text { s] }}\end{array}$ & $\begin{array}{c}\eta \\
{[\%]}\end{array}$ \\
\hline $\begin{array}{c}\text { cooling water } \\
\mathbf{R}\end{array}$ & 8.2 & - & 3.5 & - \\
\hline $\mathrm{H}$ & 2.2 & 73 & - & - \\
\hline $\mathrm{CH}_{3}$ & 3.9 & 52 & 4.0 & -14 \\
\hline $\mathrm{CH}_{3} \mathrm{CH}_{2}$ & 5.8 & 29 & 6.0 & -71 \\
\hline $\mathrm{CH}_{3} \mathrm{CH}_{2} \mathrm{CH}_{2}$ & 2.3 & 72 & $1.0-$ & $71-$ \\
\hline$\left(\mathrm{CH}_{3}\right)_{2} \mathrm{CHCH}_{2}$ & 7.2 & 13 & - & -- \\
\hline $\mathrm{C}_{6} \mathrm{H}_{5}$ & 2.4 & 71 & - & - \\
\hline $\mathrm{C}_{6} \mathrm{H}_{5} \mathrm{CH}_{2}$ & 4.1 & 50 & - & - \\
\hline $\mathrm{HOC}_{6} \mathrm{H}_{4} \mathrm{CH}_{2}$ & 5.0 & 39 & - & - \\
\hline $\mathrm{C}_{8} \mathrm{H}_{6} \mathrm{NCH}_{2}$ & 11.4 & -39 & - & - \\
\hline $\mathrm{HOOC}\left(\mathrm{CH}_{2}\right)_{2}$ & 6.8 & 17 & - & - \\
\hline $\begin{array}{c}\text { broth } \\
\text { (Desulfovibrio } \\
\text { desulfuricans) } \\
\mathbf{R} \\
\end{array}$ & 9.7 & - & - & - \\
\hline $\mathrm{H}$ & 6.5 & 33 & - & - \\
\hline $\mathrm{C}_{6} \mathrm{H}_{5}$ & 1.5 & 85 & - & - \\
\hline
\end{tabular}

\section{Conclusion}

Each other completing techniques gave information on different phases of the microbial processes. By traditional microbiological measurements the planktonic and sessile microbial colonies, by the quartz crystal nanobalance the microbial adhesion and EPS secretion were measured and characterized. The QCNB proved to be a useful technique for valuation of biofilm formation and its inhibition. The hydrophobic or the ionic character of the chemicals can influence either the adhesion process or the EPS secretion. Methods applied parallel made the distinction possible.

\section{Acknowledgment}

The authors gratefully acknowledge support of the work done by the National Research Foundation (OTKA No:T 014464 and $T$ 020792) and by the National Committee for Technological Development (No.:96-97-69-1220). Thanks are due to Mrs. Katalin Tímár for her technical assistance. 


\section{References}

[1] R.H. Gains, Ind. Eng. Chem. 2 (1910), p. 128

[2] E.S. Beardwood, Performance Monitoring of Biofilms, CORROSION (NACE) 95, (1995) pp. 202/1-16

[3] W.G. Charaklis, K.C. Marshall, /ed./ (1990) Biofilms. John Wiley \& Sons, Inc., New York

[4] J. Bácskai, G. Láng, Gy. Inzelt, J. Electroanal. Chem. 319 (1991) pp55-69

[5] D.A. Buttry, M.D. Ward, Chem. Rev. 92 (1992), pp1355-1379

[6] Gy. Inzelt, P. Jedlovszky, K. Martinusz, P. Hudáky, Acta Chimica Hungarica 128 (1991), pp 797-805 